\title{
Variation and genetic structure of Serratula lycopifolia populations (Vill.) Kern. (Asteraceae) in Poland and adjacent regions
}

\author{
Elżbieta Cieślak* \\ Department of Vascular Plant Systematics and Phytogeography, W. Szafer Institute of Botany, Polish Academy of Sciences, Lubicz 46, 31-512 Cracow, Poland
}

\section{Abstract}

AFLPs were used to analyze the genetic variability of Serratula lycopifolia, one of the rarest plant species in Central and Western Europe, in six populations from the Wyżyna Małopolska upland (Poland), White Carpathian Mts (Slovakia and Czech Republic) and Podolian Upland (Ukraine). The results of polymorphism, PCoA and neighbor-net analyzes showed similar and relatively low genetic variation and high genetic similarity of individuals within each Polish population but there were differences between those populations. The population from Slovakia also showed comparatively high intrapopulation homogeneity and evident genetic separation from the other studied populations. Intrapopulation genetic variation was higher in the Czech and Ukrainian populations. However, AMOVA analyses revealed no significant differentiation at population and regional levels. The estimated low genetic diversity in the populations from Poland and Slovakia may be due to genetic processes such as genetic drift and inbreeding in local populations resulting from their low abundance, and does not seem characteristic of the species as a whole. These genetic analyzes make it clear that the Polish and Slovakian populations need support programmes to maintain their genetic variation. Measures should focus on increasing the number of individuals in the populations and on protecting their habitat.

Keywords: AFLP, genetic diversity, rare and threatened species, Serratula lycopifolia, Central Europe

\section{Introduction}

The level of genetic variability within populations and the differences between them are important in maintaining the evolutionary potential of species, as these are key factors in adaptation to environmental changes [1-4]. The level of genetic variability reflects the influence of a number of elements such as the mating system of a species, demographic patterns, and historical factors (e.g. genetic bottlenecks in a population's past) [5-7]. Another determinant is the number of populations of the species in a given geographical region $[8,9]$. If there are many, they can buffer the species against extinction by rapidly repopulating extirpated populations and increasing the genetic differentiation between those populations [8-10]. Population size also plays a role in maintaining the genetic variation of species. In small populations the loss of even a few individuals may lead to irreversible changes in the genetic structure by decreasing genetic variation $[5,11]$. This is especially dangerous when the loss takes place over a short period of time, usually

\footnotetext{
*Email: e.cieslak@botany.pl

Handling Editor: Krzysztof Spalik
}

This is an Open Access digital version of the article distributed under the terms of the Creative Commons Attribution 3.0 License (creativecommons.org/licenses/by/3.0/), which permits redistribution, commercial and non-commercial, provided that the article is properly cited. as a result of agricultural activity. In view of all these factors, to conserve populations of endangered species it is necessary to analyze their genetic variability and diversity in addition to their demography [12-14].

Serratula lycopifolia (Vill.) Kern. is a very rare species in Central and Western Europe, belonging to the Pontic-Pannonian geographical element $[15,16]$. Its total geographical range extends from Western to Eastern Europe (southern Russia), with its distribution center in southeastern Europe. S. lycopifolia grows on sunny or slightly shaded, grassy but also bushy hillsides, on deep, rather heavy-textured soils formed on loesses or limestone rich in minerals. It occurs in both lowlands and hilly areas [17-22]. The abundance of populations varies within the geographical range, which can be divided into two parts: western, with disjunct populations, and southeastern, where the species range is continuous [15]. This uneven distribution means that the level of endangerment differs across the species range. It is low in the southeastern part of the range where the populations are numerous and large [23] but significantly high in the western and central parts of the range where the populations are few and small. Not only are the S. lycopifolia populations small and declining through most of its range [20]; several other threats to this species have been reported: abandonment of grassland and subsequent vegetation succession, intensification of agriculture, overgrazing, modification of agricultural practices, and, locally, urbanization [24]. S. lycopifolia is considered threatened and is included in several national red lists and books (e.g. [20,22,24-29]). It is also recognized as a priority species for biodiversity conservation under Annex II to the Habitat Directive under the Accession Treaty of 2003. 
Due to the character of the threats, the conservation strategy for this species needs to incorporate measures on both habitat and population levels, and should aim to maintain the genetic variability of this rare species $[20,22]$. The genetic variation of Serratula lycopifolia has not been studied heretofore. Knowledge of the genetic structure and variation of such scattered-distribution species is of special importance since it can be used to identify genetically unique subgroups across the species range. It can also be helpful in selecting populations for protection and in setting guidelines for seed collection and the establishment of new populations [30,31]. Thus it can contribute to better planning and more effective action to conserve populations of rare and threatened species.

This study was designed to assess the variation patterns of Serratula lycopifolia in island populations and in populations within its continuous range. Six populations of S. lycopifolia were selected for analysis, originating from the Wyżyna Małopolska upland in Poland, from the White Carpathian Mts in Slovakia and the Czech Republic, and from the Podolian Upland in Ukraine. The populations from the Wyżyna Małopolska upland and the nearby White Carpathian Mts are island populations in this part of the species range. The Podolian Upland population is directly adjacent to the populations of the continuous range [15]. For the very small populations from Poland (Wyżyna Małopolska upland) and Slovakia (White Carpathian Mts) such analyses may yield additional information on the dynamics of changes in variation and their potential influence on the genetic variability and structure of these populations.

This study of genetic variability in Serratula lycopifolia sought answers to these questions: $(i)$ what are the levels of genetic variability within and between the studied populations of S. lycopifolia; (ii) how great are the genetic differences between geographical regions; (iii) do the Polish populations, as examples of island populations, differ genetically (in terms of diversity and differentiation) from the populations in adjacent areas; (iv) what measures should be used to implement a strategy to preserve the genetic pool of the Polish populations and to maximize genetic diversity for ex-situ conservation?

\section{Material and methods}

\section{Population characteristics}

Samples of Serratula lycopifolia from six populations were taken: two populations from the Wyżyna Małopolska upland in Poland (Pgr, Psk), two populations from the White Carpathian Mts (one in Slovakia, Sbk; one in the Czech Republic, Cbk), and two from the Podolian Upland in Ukraine (Ucg, Ucz; Fig. 1, Tab. 1).

Serratula lycopifolia is one of the rarest species of the Polish flora $[16,18]$. It has been reported from two localities, both in the Wyżyna Małopolska upland. One locality (Psk) is on the border of the Skorocice Reserve near Skorocice village and has been known since 1959 [17]. The second locality (Pgr) is in Górki village and was discovered in 2008 [32,33] (Fig. 2). In these two localities, S. lycopifolia grows in patches of xerothermic grassland of the Thalictro-Salvietum pratensis association (Festucetalia valesiacae order, Festuco-Brometea class) [17,33,34] on hillsides covered by deep rendzina developed on gypsum. The populations cover small areas $\left(\mathrm{ca} .45 \mathrm{~m}^{2}\right.$ ) and are formed of few individuals $[32,33]$. The $S$. lycopifolia population in the Skorocice Reserve is being systematically monitored as part of the national monitoring programme for rare and endangered vascular plants [32]. Long-term regular observations show that it has a clumped distribution, with evident fluctuations in population number, from 20 to 200 (up to 400 in some years); flowering plants represent from $0 \%$ to ca. $50 \%$ of all individuals in a given year [32] (also Perzanowska personal communication 2011). Seedlings have been recorded regularly at the locality in Skorocice village. Recent observations of the population in Górki village showed that the species reproduces both vegetatively and generatively [33].

In Slovakia only one locality of the species (Sbk) is known. This locality, on Žalostiná hill in the White Carpathians, has been known since 1999 [20]. In abundance and area covered it resembles the Polish populations. Its size ranges from ca. 50 to 500 individuals and it covers only a few square meters [22,25].

In the Czech Republic there are 9 localities of Serratula lycopifolia in the southeastern part of the country: 5 in southern Moravia and 4 in the White Carpathians [20,22]. One of the latter populations (Cbk) was included in the present study. It consists of a few thousand individuals at present [35] and covers ca. 250000 square meters. In both Slovakia and the Czech Republic, S. lycopifolia grows in patches of grassland with large shares of species of the Bromion erecti and Cirsio-Brachypodion pinnati alliances (Festuco-Brometea class) [20].

During sampling, the studied populations in Poland, Slovakia and the Czech Republic did not differ from the descriptions given in the literature $[20,22,33,35]$ and summarized above.

In Ukraine, S. lycopifolia is more frequent and the populations are large and very abundant [23]. The larger areas covered and the lack of clear limits between individual plants often cause difficulty in assessing their size. During the study the number of flowering plants in the Ukrainian populations (Ucg and Ucz) ranged from 80 to ca. 130 (personal observation.). The species grows in patches of xerothermic grassland associations of the order Festucetalia valesiacae (Festuco-Brometea class) [17].

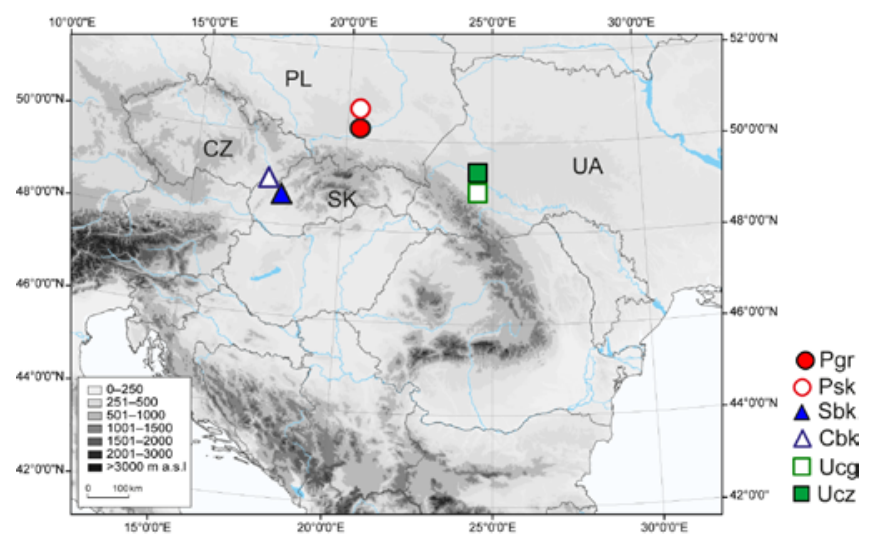

Fig. 1 Sample locations of 6 Serratula lycopifolia populations used in this study. Abbreviations of population names are given in Tab. 1.

\section{Sampling}

All material was collected during one vegetative season in June 2010. The number of samples taken from a single collecting site depended on the current abundance of the population. In each of the 6 described populations, Serratula lycopifolia was collected from the largest possible area inhabited by the species. Only well-developed stem leaves were collected from 15 to 30 randomly chosen individuals per population. A fragment of 
Tab. 1 Geographic origin and genetic parameters of Serratula lycopifolia populations.

\begin{tabular}{|c|c|c|c|c|c|c|c|c|}
\hline Abb. & Geographical region, locality & Lat. (N)/Lon. (E) & $N$ & Poly $/ \%_{\text {poly }}$ & $M_{\mathrm{d}} / \boldsymbol{M}_{\mathrm{p}}$ & $M_{\mathrm{H}}( \pm S D)$ & $M_{\mathrm{S}}( \pm S D)$ & $\boldsymbol{M}_{\mathrm{DW}}$ \\
\hline & Wyżyna Małopolska upland; Niecka & & 32 & $165 / 62.98 \%$ & $0 / 4$ & $0.21 \pm 0.19$ & $0.31 \pm 0.28$ & \\
\hline & Nidziańska region & & & & & & & \\
\hline Pgr & PL, E Wiślica, Górki* & $50^{\circ} 20^{\prime} / 20^{\circ} 43^{\prime}$ & 20 & $117 / 44.66 \%$ & $2 / 8$ & $0.14 \pm 0.19$ & $0.22 \pm 0.27$ & 151.89 \\
\hline \multirow[t]{2}{*}{ Psk } & PL, "Skorocice" reserve* & $50^{\circ} 25^{\prime} / 20^{\circ} 40^{\prime}$ & 12 & $125 / 47.71 \%$ & $0 / 9$ & $0.16 \pm 0.19$ & $0.24 \pm 0.27$ & 36.46 \\
\hline & White Carpathian Mts & & 45 & $177 / 67.56 \%$ & $0 / 6$ & $0.22 \pm 0.19$ & $0.33 \pm 0.27$ & \\
\hline Sbk & $\begin{array}{l}\text { SK, Žalostiná hill, settlement of U } \\
\text { Chalupov }^{* *}\end{array}$ & $48^{\circ} 49^{\prime} / 17^{\circ} 25^{\prime}$ & 15 & $68 / 25.95 \%$ & $2 / 9$ & $0.09 \pm 0.17$ & $0.14 \pm 0.25$ & 63.62 \\
\hline \multirow[t]{2}{*}{ Cbk } & CZ, E Veselí nad Moravou ${ }^{* \star \star}$ & $48^{\circ} 53^{\prime} / 17^{\circ} 31^{\prime}$ & 30 & $166 / 63.36 \%$ & $0 / 2$ & $0.21 \pm 0.19$ & $0.31 \pm 0.28$ & 171.83 \\
\hline & Podolian Upland; Opilya region & & 31 & $164 / 62.60 \%$ & $0 / 2$ & $0.21 \pm 0.19$ & $0.32 \pm 0.27$ & \\
\hline Ucg & UA, E Rogatin, Chertova Gora ${ }^{* * *}$ & $49^{\circ} 13^{\prime} / 24^{\circ} 41^{\prime}$ & 16 & $154 / 58.78 \%$ & $0 / 0$ & $0.18 \pm 0.18$ & $0.28 \pm 0.27$ & 44.37 \\
\hline $\mathrm{UcZ}_{\mathrm{C}}$ & UA, SE Burshtin, Kasova Gora ${ }^{* * *}$ & $49^{\circ} 24^{\prime} / 24^{\circ} 40^{\prime}$ & 15 & $149 / 56.87 \%$ & $0 / 2$ & $0.19 \pm 0.19$ & $0.28 \pm 0.28$ & 44.36 \\
\hline Total & & & 108 & $190 / 72.52 \%$ & & $0.24 \pm 0.18$ & $0.37 \pm 0.26$ & \\
\hline
\end{tabular}

Abb. - population abbreviations; Lat. - latitude; Lon - longitude; $N$ - number of individuals; Poly/ $\%_{\text {poly }}$ - number of polymorphic bands/ percentage of polymorphic bands; $M_{\mathrm{d}}$ - discriminating; $M_{\mathrm{DW}}$ - rarity of markers expressed by frequency-down-weighted marker values; $M_{\mathrm{H}}-$ Nei gene diversity index; $M_{\mathrm{p}}$ - private bands; $M_{\mathrm{s}}$ - Shannon information index; SD - standard deviation. Country: CZ - Czech Republic; PL - Poland; SK - Slovakia; UA - Ukraine. Collectors: ${ }^{\star}$ Elżbieta Cieślak; ${ }^{\star \star ~ S t a n i s l a v ~ S ̌ p a n i e l, ~ P a v o l ~ M e r e d a, ~ I v e t a ~ S ̌ k o d o v a ́ ; ~}{ }^{* \star \star ~ E . ~ C i e s ́ l a k, ~ I v a n a ~}$ Jongepierová; ${ }^{\star * * *}$ E. Cieślak, Alexander A. Kagalo.

one leaf from one individual constituted a single sample. Each leaf fragment was placed in a plastic container filled with silica gel upon collection. A total of 108 samples were stored at room temperature in silica gel until DNA extraction.

\section{DNA extraction and AFLP analyses}

Total DNA was extracted from 10-15 mg dried leaf tissue using the DNeasy Plant Mini Kit system (Qiagen) according to the manufacturer's protocol. The final elution step was carried out using $2 \times 50 \mu$ l elution buffer. The concentration and quality of the extracted DNA were estimated against a $\lambda$-DNA concentration gradient on $1 \%$ agarose gel stained with ethidium bromide.

AFLP analysis followed the methods of Vos et al. [36] with modifications as described in detail by Ronikier et al. [37]. The first step in performing AFLP was to test method reproducibility and the primer sets [38]. Three samples from each study population were used. The tests used duplicates of each individual and ten primer pairs. Sets with reproducibility over $95 \%$ and even and distinct band images were used for further investigations. Three pairs of selective primers were chosen: EcoRI-ACG/MseI-CAA, EcoRI-AGG/MseI-CTG and EcoRI-ATG/MseI-CAT.

All EcoRI selective primers were 5'-fluorescence-labelled (6-FAM). Twentyfold-diluted selective amplification products were separated with a GeneScan-500 ROX (Applied Biosystems) internal size standard, using POP 7 polymer on an ABI PRISM 3130 sequencer (Applied Biosystems).

\section{Data analysis}

The level of genetic variability was estimated as the percentage of polymorphic markers $\left(\%_{\text {poly }}\right)$, Shannon information index $\left(M_{\mathrm{S}}\right)$ [39] and Nei gene diversity index $\left(M_{\mathrm{H}}\right)$ [40], calculated using POPGENE ver. 1.21 [41]. The numbers of distinguishing bands for populations were quantified using the following criteria: $(\boldsymbol{i})$ discriminating bands $\left(M_{\mathrm{d}}\right)$, present in all analysed samples of a respective population and absent elsewhere, and (ii) private bands $\left(M_{\mathrm{p}}\right)$, unique to the respective population but not common to all of its samples [42]. Frequency-downweighted marker values for populations $\left(M_{\mathrm{DW}}\right)$ [43] were used as another standardized measure of divergence and identification of long-term isolation, calculated using AFLPdat [44].

Intra- and interpopulation relationships were analyzed based on the Nei and Li distance matrix [45] with principal coordinates analysis (PCoA) using FAMD 1.108 beta [46] and the neighbor-net method implemented in SPLITStree 4.10 [47]. Support for the branches was estimated using the bootstrap procedure (10000 iterations). Gene flow was roughly estimated using POPGENE 1.21 [41] as $N m=0.25\left(1-F_{\mathrm{ST}}\right) / F_{\mathrm{ST}}$ [48], where $F_{\mathrm{ST}}$ (fixation index) was calculated by the method of Wright [49].

Molecular variance analysis (AMOVA) was performed at two levels: within populations and between groups (defined as geographical regions). Data were analyzed using ARLEQUIN 3.11 [50], in which the fixation index, $F_{\mathrm{ST}}$ [49], was also estimated. Significance levels were determined by 1023 permutations. The Bayesian clustering algorithm for spatial population genetic analyses was implemented using TESS 2.3 [51], which can perform both individual geographical assignment and admixture analysis. It is designed to seek genetic discontinuities in continuous populations and to estimate spatially varying individual admixture proportions. Given individual geographical locations, the programme builds a network structure, which describes the geographical relationships between individuals. TESS returns genetic displays of geographical cluster assignments or admixture proportions (depending on the model used) and textual output of the admixture Q matrix [51-53]. The entire data set was examined, adding geographic coordinates for each individual using the admixture model, with 7000 iterations with a burn-in of 200 for each run, for maximal number of clusters $(K)$ equal to $2-5$, and 60 runs for each $K$. The spatial interaction parameter was 

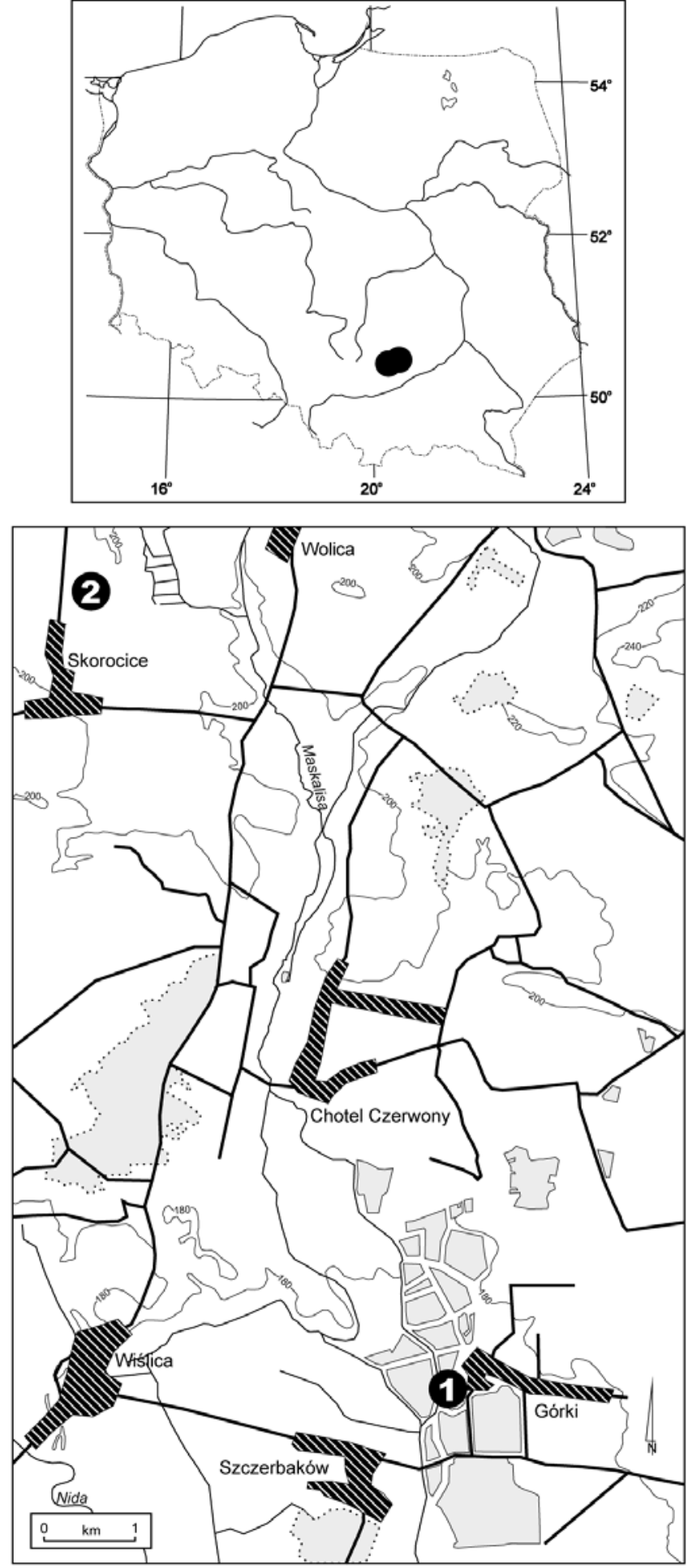

Fig. 2 Distribution map of Serratula lycopifolia in Poland. Site locations: 1 - Górki, 2 - Skorocice Reserve.

set at 0.6 . Finally $K$ was estimated from the $20 \%$ of the runs with the highest data likelihood. Similarity coefficients between runs and the average matrix of ancestry membership were calculated using CLUMPP 1.1 [54]. To choose the number of optimal clusters, $K$ was determined on the basis of the criteria set by Durand et al. [53]. The differences between the genetic variability parameters of population groups were estimated with the Mann-Whitney U-test using Statistica 5.0.

The parameters estimating genetic diversity were calculated assuming Hardy-Weinberg equilibrium.

\section{Results}

A total of 262 DNA markers were recorded in 108 individuals of Serratula lycopifolia, and 190 polymorphic bands were detected $(72.52 \%)$. The genetic variation parameters were as follows: Nei gene diversity index $M_{\mathrm{H}}=0.24(S D=0.18)$, Shannon index $M_{\mathrm{S}}=0.37(S D=0.26)$. The coefficient of gene flow between the six populations was relatively high at $N m=2.003$.

The number of polymorphic bands within populations ranged from 68 in population Sbk (Slovakia) to 166 in Cbk (Czech Republic), with a mean of 129.83 per population $(S D=35.41)$. Two discriminating bands were recorded in each of two populations: Pgr (Poland) and Sbk (Slovakia). The number of private bands ranged from 2 in Cbk (Czech Republic) and Ucz (Ukraine) to 9 in Sbk (Slovakia) and Psk (Poland). The other Polish population (Pgr) had 8 private bands, almost as high as Psk. Private bands were not detected in Ucg (Ukraine). The $M_{\mathrm{H}}$ and $M_{\mathrm{S}}$ index values were lowest for Sbk (Slovakia) at $M_{\mathrm{H}}=0.09(S D=0.17)$ and $M_{\mathrm{S}}=0.14(S D=0.25)$, and highest for Cbk (Czech Republic) at $M_{\mathrm{H}}=0.21(S D=0.19)$ and $M_{\mathrm{S}}=0.31$ $(S D=0.28)$. The means for all populations taken together were $M_{\mathrm{H}}=0.16(S D=0.04)$ and $M_{\mathrm{S}}=0.25(S D=0.06) \cdot M_{\mathrm{DW}}$ ranged from 36 for Psk (Poland) to 171 for Cbk (Czech Republic), with a mean value of $85.42(S D=60.21$; Tab. 1$)$.

Polymorphism analysis showed a very uniform level of within-region variation. There were no significant differences in the values of the Nei gene diversity index, Shannon index and number of polymorphic bands between regions (Tab. 1). Discriminating bands were not found for any group of populations. The number of private bands was lowest for the Podolian Upland ( 2 bands) and highest for the White Carpathian Mts (6 bands). The $M_{\mathrm{DW}}$ index differed greatly between populations in two regions: the Wyżyna Małopolska upland and the White Carpathian Mts: $M_{\mathrm{DW}}=151.89$ for Pgr and $M_{\mathrm{DW}}=36.64$ for Psk in the Wyżyna Małopolska upland; and $M_{\mathrm{DW}}=171.83$ for Cbk and $M_{\mathrm{DW}}=63.62$ for Sbk in the White Carpathian Mts. The $M_{\mathrm{DW}}$ values for the populations in the Podolian Upland were uniform (Tab. 1).

PCoA separated three groups of Serratula lycopifolia individuals along axis 1 (22.52\% of total variation) and axis 2 (13.20\%): those in population Pgr, those in population Sbk, and the rest (Psk, Cbk, Ucg, Ucz). The first two (Pgr, Sbk) distinctly differ genetically from each other and from the other populations (Fig. 3).

The dendrogram based on Nei and Li genetic distance confirmed the pattern obtained from PCoA for the high genetic divergence of populations Sbk (Slovakia) and Pgr (Poland) from the others. The other Polish population (Psk) also differs genetically from the other populations, with more than $60 \%$ bootstrap support. The Ukrainian and Czech populations form a group separate from those (bootstrap 35\%), and with no evident internal variation. Subgroups corresponding to particular populations can be distinguished but with less than 15\% bootstrap support (Fig. 4).

High intrapopulation variation $(63.76 \%)$ and considerably less interpopulation variation (36.90\%) were found by AMOVA $\left(F_{\mathrm{ST}}=0.36, P<0.001\right)$. The primacy of intrapopulation variation was also shown by hierarchical AMOVA for the geographical regions (three groups). The differences between regions were not significant in either case (Tab. 2).

The gene flow coefficient varied greatly depending on the population group: very high between populations in the Podolian Upland $(\mathrm{Nm}=6.89)$ and much lower between populations 

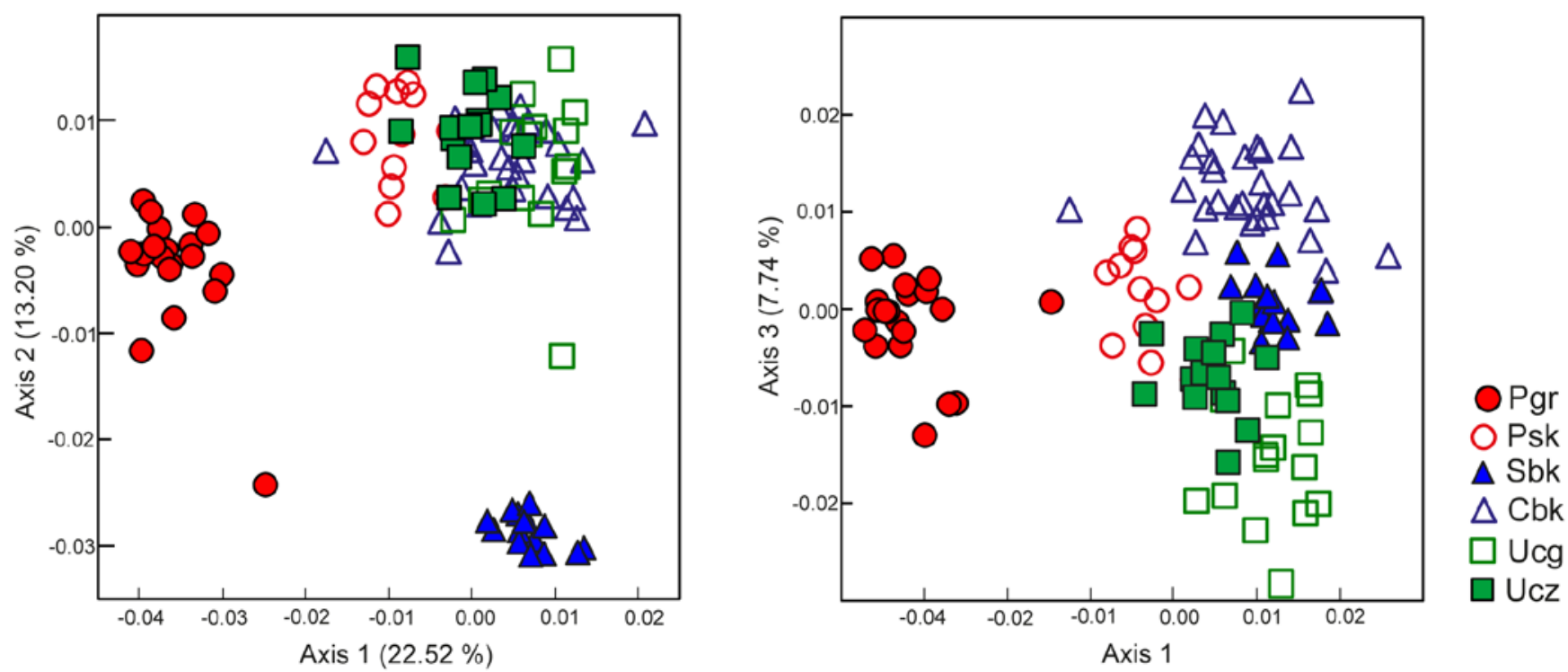

Fig. 3 Principal coordinate analysis (PCoA) of Serratula lycopifolia individuals based on Nei and Li distance of AFLP phenotypes. Pgr, Psk (circles) - Wyżyna Małopolska upland; Cbk, Sbk (triangles) - White Carpathian Mts; Ucg, Ucz (squares) - Podolian Upland. Abbreviations of population names are given in Tab. 1.

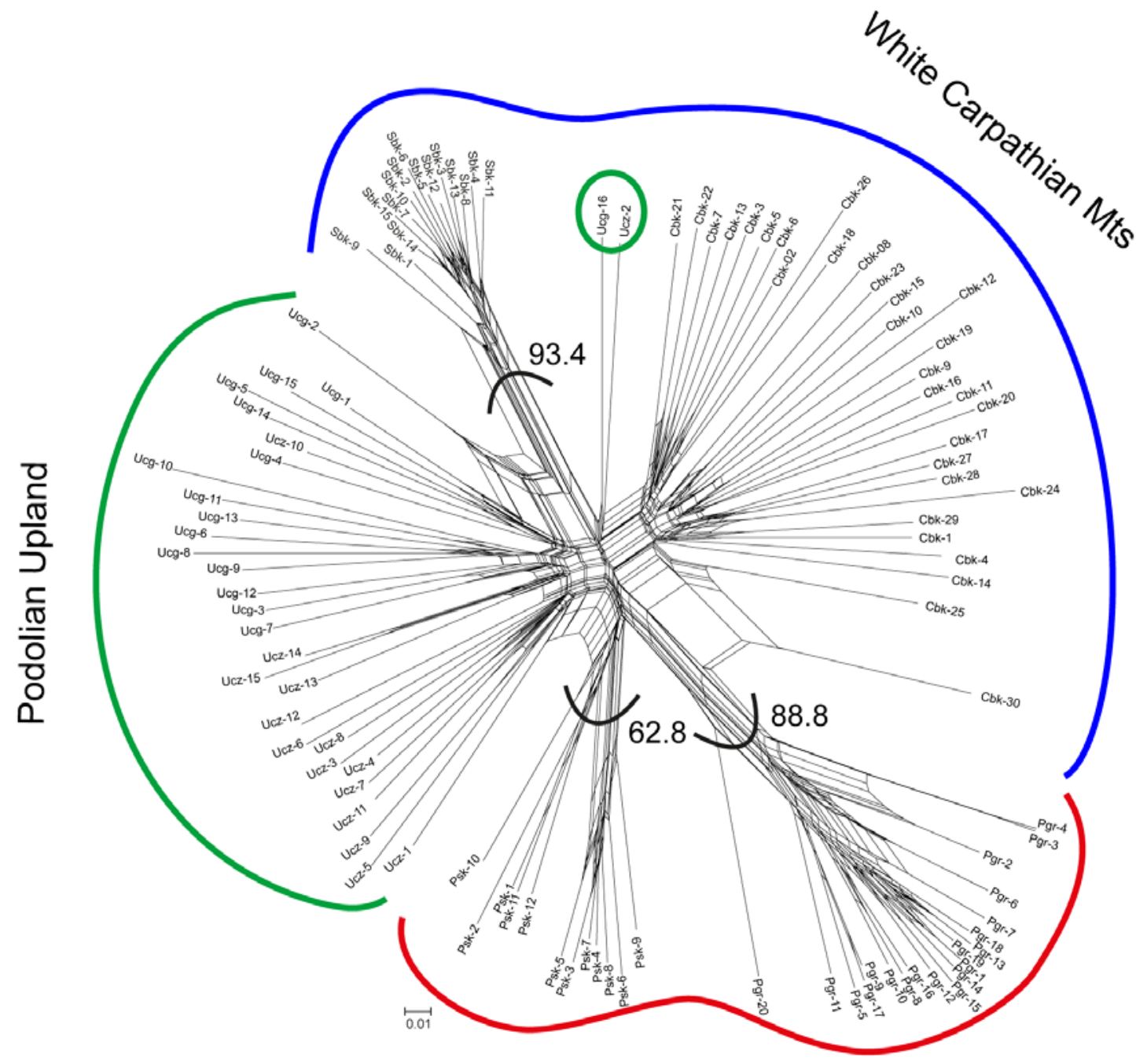

\section{Wyżyna Małopolska upland}

Fig. 4 Neighbour-net tree of Serratula lycopifolia individuals (AFLP data) based on Nei and Li distance coefficients. Bootstrap values above $60 \%$ are given at nodes. Abbreviations of population names are given in Tab. 1. 
Tab. 2 Analyses of molecular variance (AMOVA) based on AFLP markers for Serratula lycopifolia (significance tests - 1023 permutations).

\begin{tabular}{|c|c|c|c|c|c|}
\hline Source of variation & d.f. & Sum of squares & Variance components & Percentage of variation & $F, P$ \\
\hline \multicolumn{6}{|l|}{ All individuals } \\
\hline Among populations & 5 & 1349.12 & 13.92 & 36.24 & \\
\hline Within populations & 102 & 2499.16 & 24.51 & 63.76 & $F_{\mathrm{ST}} 0.36^{*}$ \\
\hline Total & 107 & 3848.28 & 38.42 & - & \\
\hline Among 3 geographical groups & 2 & 652.69 & 1.96 & 5.08 & $F_{\mathrm{CT}} 0.05, P<0.146$ \\
\hline Among populations within groups & 3 & 696.45 & 12.34 & 31.79 & $F_{\mathrm{SC}} 0.33^{*}$ \\
\hline Within populations & 102 & 2499.16 & 24.51 & 63.13 & $F_{\text {ST }} 0.36^{*}$ \\
\hline Total & 107 & 3848.28 & 38.81 & - & \\
\hline $\begin{array}{l}\text { Polish populations versus remaining } \\
\text { populations }\end{array}$ & 1 & 440.11 & 4.531 & 11.15 & $F_{\mathrm{CT}} 0.11, P<0.061$ \\
\hline Among populations within groups & 4 & 909.01 & 11.61 & 28.56 & $F_{\mathrm{SC}} 0.32^{*}$ \\
\hline Within populations & 102 & 2499.16 & 24.51 & 60.29 & $F_{\mathrm{ST}} 0.39^{*}$ \\
\hline Total & 107 & 3848.28 & 40.64 & - & \\
\hline
\end{tabular}

${ }^{\star} P<0.001$.

in the Wyżyna Małopolska upland $(\mathrm{Nm}=1.27)$ and in the White Carpathian Mts $(\mathrm{Nm}=1.53)$. Inter-regional gene flow was very low $(\mathrm{Nm}<1)$ between the Wyżyna Małopolska upland and the White Carpathian Mts $(\mathrm{Nm}=0.84)$. The gene flow coefficient exceeded 1 for the White Carpathian Mts versus the Podolian Upland $(\mathrm{Nm}=1.61)$ and for the Wyżyna Małopolska upland versus the Podolian Upland $(\mathrm{Nm}=1.33)$.

The genetic divergence of population Pgr (Wyżyna Małopolska upland) from all the other populations was confirmed with the Bayesian algorithm (TESS analysis) for $K=2$. Population Sbk (Slovakia) also formed a group genetically separate from the remaining populations for $K=3$. The remaining populations from different geographical regions (Psk, Poland; Cbk, Czech Republic; Ucg and Ucz, Ukraine) formed a homogeneous gene pool (Fig. 5).

\section{Discussion}

For the Polish populations of Serratula lycopifolia, these analyses showed similar levels of within-population genetic variation, genetic divergence between populations, and high genetic similarity of individuals within each population; this was particularly evident in the Górki village population (Pgr). The population from Slovakia (Sbk) showed comparably high intrapopulation homogeneity and evident genetic divergence from both Ukrainian populations (Ucg and Ucz) and from the Czech population (Cbk).

However, AMOVA revealed high variation within population and the absence of significant differences in genetic variation between regions. This result seems to indicate that the estimated low genetic variation in the Slovakian and the two Polish populations results from the influence of genetic processes such as genetic drift and inbreeding in local populations due to low abundance.

Genetic drift leads to reduced genetic variation by randomly fixing and/or eliminating individual alleles in small populations $[2,3,11]$. An impoverished genetic structure leads to qualitative changes that can hamper the adaptation processes of a species, including those associated with environmental changes [2,55]. A quick and/or long-term drop in abundance leads to a population bottleneck [55-57]. When the number of individuals in a population is low, the effect of genetic drift and inbreeding is exacerbated, and both processes lead to a drop in genetic variation. Inbreeding, mating of closely related individuals, leads to increased homozygosity in a population and decreased genetic variation $[1,3,58]$. Homozygosity cannot be directly calculated by the methods used in this analysis (due to the use of dominant markers) but the very high genetic similarity of individuals (as reflected in the dendrogram and parameter values) in population Pgr from Poland and population Sbk from Slovakia may be indicators of it.

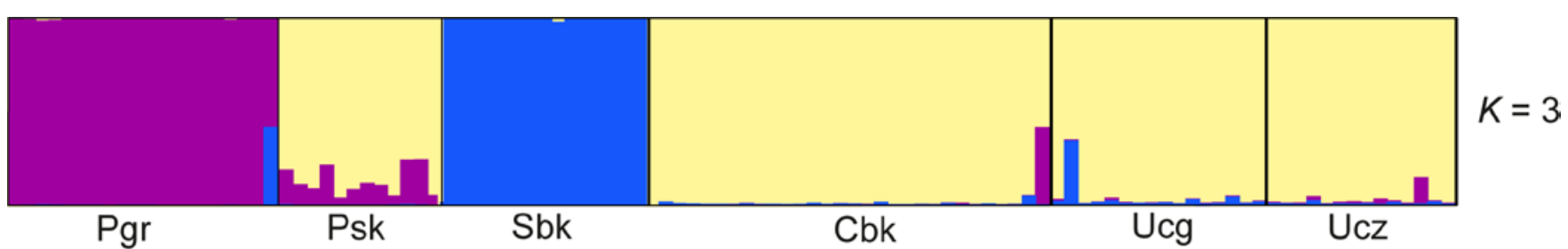

Fig. 5 TESS analysis for Serratula lycopifolia. Bar graph of population assignment of individuals for $K=3$. The populations are separated by vertical lines. Abbreviations of population names are given in Tab. 1. 
Gene flow also affects the level of genetic variation of a population. In the case of an island distribution, the large distance between populations often hinders or even blocks gene flow, leading to increased differentiation between populations and to gradually reduced variability within each one $[59,60]$. The value for gene flow in the Wyżyna Małopolska upland and White Carpathian Mts populations is much lower than the corresponding value for the Podolian Upland populations, which are next to the continuous range. Such a very large difference in gene flow values testifies to the island distribution of the first pair. It also shows that the distance between these populations of Serratula lycopifolia is large, and hinders or blocks of gene flow. On the other hand, the relatively high gene flow between S. lycopifolia populations within regions (values of $\mathrm{Nm}>1$ for regions) may be due to the absence of factors preventing intense gene flow in their past history [61]. In relation to the Ukrainian populations, the Polish, Slovakian and Czech populations are at the species range limit. Their intrapopulation genetic variation is lower than that of the Ukrainian populations.

The lower genetic variation of the populations at the range limit may be the result of the founder effect [62], when a small group of individuals representing the entire gene pool of the species becomes the only source of genetic variation at a new site. If the founder population does not develop rapidly, the persistence of a small number of individuals can also increase inbreeding in the population. A rapid increase in the abundance of a population can counteract the effect of inbreeding $[42,63]$. This can be observed in the Czech population, which is very abundant at present, having reached its current size as a result of regular conservation management. The genetic variation values of this population are considerably higher than for the Slovakian and the two Polish populations, and are similar to those of the Ukrainian populations. It is difficult to establish whether that is only the result of increased abundance, but the correlation between genetic variation and population abundance presents strong confirmation. Seedlings have been observed in population Psk in Poland (monitoring data) but the population does not seem to be restoring itself effectively, based on the low number of individuals persisting over time (ca. 200 on average). Conservation measures are needed there to increase its population size. The development of the Czech S. lycopifolia population shows that appropriate treatment can increase the population's abundance and genetic variation, improving its chance of survival. As part of comprehensive biodiversity protection, the genetic variation of S. lycopifolia needs to be protected in each region where it still occurs in Poland and the rest of Europe, so that the entire gene pool of the species can be preserved, as its populations are highly disjunct in this part of its range.

Besides the need to increase the population numbers, it is important to protect the habitats of this species. The main threat to this photophilous species comes from natural successional processes within the patches. Species including expansive grasses (e.g. Bromus inermis, Calamagrostis epigejos) and bushes, especially juvenile Prunus spinosa, are encroaching [32] (also Perzanowska personal communication 2011). Succession processes are reinforced by the decline of traditional agricultural practices near those sites in recent years; neighboring patches are left fallow, and grazing or mowing have been abandoned. Hence, the need for active protection of Serratula lycopifolia that should involve the removal of emerging trees and shrubs and periodic mowing. This is especially important for the populations in Western Europe, representing the northwestern distribution limit of S. lycopifolia.
Despite the differences in genetic variation in the populations, molecular variance analysis showed a high contribution of intrapopulation variation to the variation between geographical groups. Attributes such as life form, geographical range and breeding system influence the genetic structure of each species. Long-lived, perennial, widespread, outcrossing species generally show more genetic diversity than short-lived, selfing or mixed-mating, narrow endemic species $[63,64]$. Serratula lycopifolia is a long-lived perennial herb with a mixed-mating breeding system. Such higher genetic variability within rather than between populations as observed in S. lycopifolia is typical for outcrossing perennial plant species $[64,65]$. It may result from particular life history traits of $S$. lycopifolia, such as the combination of sexual and vegetative reproduction or its long life span. Those features tend to preserve genetic variability within populations [66]. Similar high levels of intrapopulation diversity have been demonstrated in other disjunctly distributed taxa [42,67-71].

The diversity of Serratula lycopifolia populations (Poland, Slovakia), which does not correlate with the geographical region of the populations, along with the dominance of intrapopulation variation, are indicative of the high genetic variability of this species. This is surprising, as some of these populations are in geographical areas isolated from each other by the Carpathians. Further phylogeographical investigations incorporating material from the entire species range are needed to determine the genetic structure of S. lycopifolia.

\section{Acknowledgments}

I thank Joanna Perzanowska for providing monitoring data on the Polish populations of S. lycopifolia, Stanislav Španiel, Pavol Mereda and Iveta Škodová for collecting the samples from Slovakia, and Ivana Jongepierová and Alexander A. Kagalo for their advice on selection of localities and for their kind assistance during my field trips to the Czech Republic and Ukraine, respectively. For the part of the study done in Poland, samples were collected and stored under permits from the regional Office of Environmental Protection in Kielce. Funding for this work from the National Science Centre (Poland, grant No. N 3041546 33) is gratefully acknowledged.

\section{References}

1. Charlesworth D, Charlesworth B. Inbreeding depression and its evolutionary consequences. Annu Rev Ecol Syst. 1987;18(1):237-268. http://dx.doi. org/10.1146/annurev.es.18.110187.001321

2. Ellstrand NC. Population genetic consequences of small population size: implications for plant conservation. Annu Rev Ecol Syst. 1993;24(1):217242. http://dx.doi.org/10.1146/annurev.ecolsys.24.1.217

3. Young A, Boyle T, Brown T. The population genetic consequences of habitat fragmentation for plants. Trends Ecol Evol. 1996;11(10):413-418. http:// dx.doi.org/10.1016/0169-5347(96)10045-8

4. Reed DH, Frankham R. Correlation between fitness and genetic diversity. Conserv Biol. 2003;17(1):230-237. http://dx.doi. org/10.1046/j.1523-1739.2003.01236.x

5. Barrett SCH, Kohn J. The genetic and evolutionary consequences of small population size in plant: implications for conservation. In: Falk DA, Holsinger KE, editors. Genetics and conservation of rare plants. New York: Oxford University Press; 1991. p. 3-30.

6. Honnay O, Bossuyt B. Prolonged clonal growth: escape route or 
route to extinction? Oikos. 2005;108(2):427-432. http://dx.doi. org/10.1111/j.0030-1299.2005.13569.x

7. Kang M, Wang J, Huang H. Demographic bottlenecks and low gene flow in remnant populations of the critically endangered Berchemiella wilsonii var. pubipetiolata (Rhamnaceae) inferred from microsatellite markers. Conserv Genet. 2007;9(1):191-199. http://dx.doi.org/10.1007/s10592-007-9324-0

8. Hanski I. Metapopulation dynamics. Nature. 1998;396(6706):41-49. http:// dx.doi.org/10.1038/23876

9. Lammi A, Siikamaki P, Mustajarvi K. Genetic diversity, population size, and fitness in central and peripheral populations of a rare plant Lychnis viscaria. Conserv Biol. 1999;13(5):1069-1078. http://dx.doi. org/10.1046/j.1523-1739.1999.98278.x

10. Conservation of rare or little-known species: biological, social, and economic considerations. Washington: Island Press; 2007.

11. Keller L, Waller DM. Inbreeding effects in wild populations. Trends Ecol Evol. 2002;17(5):230-241. http://dx.doi.org/10.1016/ S0169-5347(02)02489-8

12. Lande R. Genetics and demography in biological conservation. Science. 1988;241(4872):1455-1460. http://dx. doi.org/10.1126/science.3420403

13. Escudero A. Spatial analysis of genetic diversity as a tool for plant conservation. Biol Conserv. 2003;113(3):351-365. http://dx.doi.org/10.1016/ S0006-3207(03)00122-8

14. Aguilar R, Quesada M, Ashworth L, Herrerias-Diego Y, Lobo J. Genetic consequences of habitat fragmentation in plant populations: susceptible signals in plant traits and methodological approaches. Mol Ecol. 2008;17(24):51775188. http://dx.doi.org/10.1111/j.1365-294X.2008.03971.x

15. Meusel H, Jäger E. Vergleichende Chorologie der zentraleuropäischen Flora. Karten, Literatur, Register. Stuttgart: Fischer; 1992. (vol 3).

16. Zając M, Zając A. The geographical elements of native flora of Poland. Cracow: Laboratory of Computer Chorology, Institute of Botany, Jagiellonian University; 2009.

17. Medwecka-Kornaś A. Roślinność rezerwatu stepowego "Skorocice" koło Buska. Ochr Przyr. 1959;26:172-260.

18. Pawłowska S. Serratula lycopifolia (Vill.) Kern. In: Pawłowski B, Jasiewicz A, editors. Flora polska. Rośliny naczyniowe Polski i ziem ościennych. Warsaw: Polish Scientific Publishers PWN; 1972. p. 394. (vol 12).

19. Cannon JFM, Marshall JB. Serratula L. In: Tutin TG, Heywood VH, Burges NA, Moore DM, Valentine DH, Walters SM, et al., editors. Flora Europaea. Cambridge: Cambridge University Press; 1976. p. 251. (vol 4).

20. Škodová I. Nález nezvestného druhu Serratula lycopifolia (Vill.) A. Kern. na Slovensku. Chránené územia Slovenska, SAŽP Banská Bystrica. 1999;41:8-10.

21. Křísa B. Serratula L. - srpice. In: Slavík B, Štěpánková J, editors. Květena České republiky. Praha: Academia; 2004. p. 423-425. (vol 7).

22. Mereda P, Hodálová I. Cievnaté rastliny. In: Halčinová K, editor. Atlas druhov európskeho významu pre územia NATURA 2000 na Slovensku. Bratislava: Slovart; 2011. p. 108-109.

23. Klokov MV. Serněj - Serratula L. In: Visülina OD, editor. Flora URSA. Kiev: Naukova Dumka; 1965. p. 8-23. (vol 12).

24. Bilz M. Klasea lycopifolia [Internet]. IUCN red list of threatened species. Version 2012.2. 2012 [cited 2012 Nov 21]; Available from: http://www. iucnredlist.org

25. Holub J, Grulich V. Klasea lycopifolia (Vill.) Á. Löve et D. Löve. In: Čeřovský J, Feráková V, Holub J, Maglocký Š, Procházka F, editors. Červená kniha ohrožených a vzácných druhů rostlin a živočichů ČR a SR. Vyššie rastliny. Bratislava: Priroda; 1999. p. 204. (vol 5).

26. Mirek Z. Serratula lykopifolia (Vill.) A. Kern. Sierpik różnolistny. In: Kaźmierczakowa R, Zarzycki K, editors. Polish red data books of plants. Pteridophytes and flowering plants. Cracow: W. Szafer Institute of Botany, Polish Academy of Sciences; 2001. p. 388-389.

27. Nikolić T, Topić J, editors. Red book of vascular flora of Croatia. Zagreb: Ministry of Culture, State Institute for Nature Protection, Republic of Croatia; 2005.
28. Mirek Z, Zarzycki K, Wojewoda W, Szeląg Z, editors. Red list of plants and fungi in Poland. Cracow: W. Szafer Institute of Botany, Polish Academy of Sciences; 2006.

29. Király G. Vörös lista: a magyarországi edényes flóra veszélyeztetett fajai. Sopron: Saját kiadás; 2007.

30. Sork VL, Nason J, Campbell DR, Fernandez JF. Landscape approaches to historical and contemporary gene flow in plants. Trends Ecol Evol. 1999;14(6):219-224. http://dx.doi.org/10.1016/S0169-5347(98)01585-7

31. Baskauf CJ, Burke JM. Population genetics of Astragalus bibullatus (Fabaceae) using AFLPs. J Hered. 2009;100(4):424-431. http://dx.doi. org/10.1093/jhered/esp033

32. Perzanowska J. Sierpik różnolistny, Serratula lycopifolia (Vill.) Kern. In: Perzanowska J, editor. Monitoring gatunków roślin. Przewodnik metodyczny. Warsaw: Chief Inspectorate Of Environmental Protection; 2010. p. 207-217. (vol 1).

33. Kruk J, Cieślak P. Nowe stanowisko sierpika różnolistnego Serratula lycopifolia na terenie niecki Nidziańskiej. Chrońmy Przyr Ojcz. 2011;67(4):354-357.

34. Matuszkiewicz W. Przewodnik do oznaczania zbiorowisk roślinnych Polski. Vademecum Geobotanicum. Warszawa: Polish Scientific Publishers PWN; 2005. (vol 3).

35. Jongepierová-Hlobilová I, Jongepier JW, Devánová K, Fajmon K, Hájek M, Škodová I. Vybrane vzácné rostliny. In: Jongepierová-Hlobilová I, editor. Louky Bílých Karpat (Grasslands of the White Carpathian Mountains). Veselí nad Moravou: ZO CSOP Bílé Karpaty; 2008. p. 101-126.

36. Vos P, Hogers R, Bleeker M, Reijans M, van de Lee T, Hornes M, et al. AFLP: a new technique for DNA fingerprinting. Nucleic Acids Res. 1995;23(21):4407-4414. http://dx.doi.org/10.1093/nar/23.21.4407

37. Ronikier M, Cieślak E, Korbecka G. High genetic differentiation in the alpine plant Campanula alpina Jacq. (Campanulaceae): evidence for glacial survival in several Carpathian regions and long-term isolation between the Carpathians and the Alps. Mol Ecol. 2008;17(7):1763-1775. http:// dx.doi.org/10.1111/j.1365-294X.2008.03664.x

38. Bonin A, Bellemain E, Bronken Eidesen P, Pompanon F, Brochmann C, Taberlet P. How to track and assess genotyping errors in population genetics studies. Mol Ecol. 2004;13(11):3261-3273. http://dx.doi. org/10.1111/j.1365-294X.2004.02346.x

39. Lewontin RC. The apportionment of human diversity. Evol Biol. 1972;6:381-398.

40. Nei M. Estimation of average heterozygosity and genetic distance from a small number of individuals. Genetics. 1978;89(3):583-590.

41. POPGENE, the userfriendly shareware for population genetic analysis [Internet]. Available from: http://www.ualberta.ca/ fyeh/popgene_download.html

42. Cieślak E, Ronikier M, Koch MA. Western Ukrainian Cochlearia (Brassicaceae) the identity of an isolated edge population. Taxon. 2007;56(1):112-118.

43. Schönswetter P, Tribsch A. Vicariance and dispersal in the Alpine perennial Bupleurum stellatum L. (Apiaceae). Taxon. 2005;54(3):725. http://dx.doi. org/10.2307/25065429

44. Ehrich D. AFLPdat: a collection of $r$ functions for convenient handling of AFLP data. Mol Ecol Notes. 2006;6:603-604. http://dx.doi. org/10.1111/j.1471-8286.2006.01380.x

45. Nei M, Li WH. Mathematical model for studying genetic variation in terms of restriction endonucleases. Proc Natl Acad Sci USA. 1979;76(10):52695273. http://dx.doi.org/10.1073/pnas.76.10.5269

46. Schluter PM, Harris SA. Analysis of multilocus fingerprinting data sets containing missing data. Mol Ecol Notes. 2006;6(2):569-572. http://dx.doi. org/10.1111/j.1471-8286.2006.01225.x

47. Huson DH. Application of phylogenetic networks in evolutionary studies. Mol Biol Evol. 2005;23(2):254-267. http://dx.doi.org/10.1093/molbev/ $\mathrm{msj} 030$

48. Slatkin M, Barton NH. A comparison of three indirect methods for 
estimating average levels of gene flow. Evolution. 1989;43(7):1349. http:// dx.doi.org/10.2307/2409452

49. Wright S. Evolution and the genetics of populations. Chicago IL: University of Chicago Press; 1978. (vol 4).

50. Excoffier L, Laval G, Schneider S. Arlequin ver. 3.0: an integrated software package for population genetics data analysis. Evol Bioinform. 2005;1:47-50.

51. Chen C, Durand E, Forbes F, François O. Bayesian clustering algorithms ascertaining spatial population structure: a new computer program and a comparison study. Mol Ecol Notes. 2007;7(5):747-756. http://dx.doi. org/10.1111/j.1471-8286.2007.01769.x

52. François $\mathrm{O}$, Ancelet $\mathrm{S}$, Guillot $\mathrm{G}$. Bayesian clustering using hidden markov random fields in spatial population genetics. Genetics. 2006;174(2):805816. http://dx.doi.org/10.1534/genetics.106.059923

53. Durand E, Chen C, François O. Comment on "On the inference of spatial structure from population genetics data”. Bioinformatics. 2009;25(14):18021804. http://dx.doi.org/10.1093/bioinformatics/btp337

54. Jakobsson M, Rosenberg NA. CLUMPP: a cluster matching and permutation program for dealing with label switching and multimodality in analysis of population structure. Bioinformatics. 2007;23(14):1801-1806. http:// dx.doi.org/10.1093/bioinformatics/btm233

55. Frankham R. Genetics and extinction. Biol Conserv. 2005;126(2):131-140. http://dx.doi.org/10.1016/j.biocon.2005.05.002

56. Nei M, Maruyama T, Chakraborty R. The bottleneck effect and genetic variability in populations. Evolution. 1975;29(1):1. http://dx.doi. org/10.2307/2407137

57. Carson HL. Increased genetic variance after a population bottleneck. Trends Ecol Evol. 1990;5(7):228-230. http://dx.doi. org/10.1016/0169-5347(90)90137-3

58. Mayr E. Change of genetic environment and evolution. In: Huxley J, Ford EB, editors. Evolution as a process. London: Allen \& Unwin; 1954. p. 157-180.

59. Mayr E. Populations, species, and evolution: an abridgment of animal species. Cambridge MA: Harvard University Press; 1970.

60. Slatkin M. Gene flow and the geographic structure of natural populations. Science. 1987;236(4803):787-792. http://dx.doi.org/10.1126/ science. 3576198
61. van Rossum F, Prentice HC. Structure of allozyme variation in Nordic Silene nutans (Caryophyllaceae): population size, geographical position and immigration history. Biol J Linn Soc. 2004;81(3):357-371. http:// dx.doi.org/10.1111/j.1095-8312.2003.00301.x

62. Templeton AR. The theory of speciation via the founder principle. Genetics. 1980;94(4):1011-1038.

63. Cieślak E, Kaźmierczakowa R, Ronikier M. Cochlearia polonica Fröhl. (Brassicaceae), a narrow endemic species of southern Poland: history of conservation efforts, overview of current population resources and genetic structure of populations. Acta Soc Bot Pol. 2010;79(3):255-261.

64. Hamrick JL, Godt MJW. Allozyme diversity in plant species. In: Brown AHD, Clegg MT, Kahler AL, Weir BS, editors. Plant population genetics, breeding and genetic resources. Sunderland MA: Sinauer Associates; 1989. p. 43-63.

65. Hamrick JL, Godt MJW. Effects of life history traits on genetic diversity in plant species. Philos Trans R Soc Lond B Biol Sci. 1996;351(1345):12911298. http://dx.doi.org/10.1098/rstb.1996.0112

66. Loveless MD, Hamrick JL. Ecological determinants of genetic structure in plant populations. Annu Rev Ecol Syst. 1984;15(1):65-95. http://dx.doi. org/10.1146/annurev.es.15.110184.000433

67. Wróblewska A, Brzosko E, Czarnecka B, Nowosielski J. High levels of genetic diversity in populations of Iris aphylla L. (Iridaceae), an endangered species in Poland. Bot J Linn Soc. 2003;142(1):65-72. http://dx.doi. org/10.1046/j.1095-8339.2003.00162.x

68. Aegisdottir HH, Kuss P, Stocklin J. Isolated populations of a rare alpine plant show high genetic diversity and considerable population differentiation. Ann Bot. 2009;104(7):1313-1322. http://dx.doi.org/10.1093/aob/mcp242

69. Cieślak E, Szeląg Z. Genetic Diversity of Galium cracoviense Ehrend. (Rubiaceae) - the Polish endemic plant. Acta Soc Bot Pol. 2009;78(2):123-129.

70. Šmídová A, Münzbergová Z, Plačková I. Genetic diversity of a relict plant species, Ligularia sibirica (L.) Cass. (Asteraceae). Flora. 2011;206(2):151157. http://dx.doi.org/10.1016/j.flora.2010.03.003

71. Stachurska-Swakoń A, Cieślak E, Ronikier M. Genetic variability of small isolated populations of Cicerbita alpina (L.) Wallr. (Asteraceae) in the Beskid Mały Mts (southern Poland). Pol J Ecol. 2011;59(2):279-288. 